\title{
Evaluation of anatomical and functional outcomes in patients undergoing repair of traumatic canalicular laceration
}

\author{
Hasan Aytoğan, M.D., ${ }^{1}$ Şeyda Karadeniz Uğurlu, M.D. ${ }^{2}$ \\ ${ }^{1}$ Department of Eye Disease, Tepecik Training and Research Hospital, Izmir-Turkey \\ ${ }^{2}$ Department of Eye Disease, Katip Çelebi University Faculty of Medicine, İzmir-Turkey
}

\begin{abstract}
BACKGROUND: The present study was designed to evaluate functional and anatomical success of traumatic canalicular laceration repair.

METHODS: Consecutive patients who presented at Atatürk Training and Research Hospital Eye Clinic, İzmir Katip Çelebi University Faculty of Medicine and had canalicular laceration repair performed by the same surgeon between January 2009 and December 2014 were included in the study. Demographic data, length of time between injury and surgery, and cause of the trauma, surgical method employed, and duration of follow-up were recorded. Postoperative epiphora was evaluated using Munk score. Patency of lacrimal system was assessed with canalicular irrigation.

RESULTS: Thirty-five male and 6 female patients were included in the study. Mean age of $4 \mathrm{I}$ participants was $31.85 \pm 18.9$ years (range: I-79 years). Avulsive injury was observed in $66 \%(n=27)$, and direct (penetrating) injury in $34 \%$ ( $n=14)$. Distribution of injured canaliculi was as follows: left inferior canaliculus $63.4 \%(n=26)$, right inferior canaliculus $19.5 \%(n=8)$, right superior canaliculus $9.8 \%$ $(n=4)$, and left superior canaliculus $7.3 \%(n=3)$. Thirty-four patients had monocanalicular tube implantation (mini-Monoka) and 10 patients had bicanalicular annular intubation using pigtail probe. Average follow-up time was $6 \pm 5.7$ months. Munk score was Grade 0 in all patients. Canalicular irrigation indicated all canaliculi were patent.
\end{abstract}

CONCLUSION: Recent microsurgical techniques result in successful repair of canalicular laceration.

Keywords: Epiphora; tear meniscus; traumatic canalicular injury.

\section{INTRODUCTION}

Canaliculi are structures that play a role in drainage of tears from the eye and are significant part of the active pump system defined by Jones. ${ }^{[1-3]}$ Risk of canalicular laceration is greater in injuries to medial eyelid and canthal region. Canalicular injury can result in epiphora and cosmetic problems. ${ }^{[4]}$ This condition is particularly seen in children and adolescents, and is often caused by incidents of trauma, such as sports-related accidents, fist fights, falling from bicycles, or traffic accidents.

Address for correspondence: Hasan Aytoğan, M.D.

Kazım Dirik Mah., 214 Sok., No: 12, Daire 4, 35100 Bornova, İzmir, Turkey

Tel: +90 232 - 4443560 E-mail: hasan_aytogan@hotmail.com

Qucik Response Code Ulus Travma Acil Cerrahi Derg 2017;23(I):66-7|

doi: $10.5505 /$ tjtes.2016.6502।

Copyright 2017

TJTES
Lacerations resulting from canalicular trauma are repaired with micro-surgical intervention. Treatment consists of maintaining patent passageway and protecting remainder of the lacrimal drainage system, in addition to repair of canalicular trauma.

The present study was an analysis of the demographic characteristics of patients treated for traumatic canalicular damage, features of the injuries causing the damage, and results of surgical treatment.

\section{MATERIALS AND METHODS}

Patients who presented at the Atatürk Training and Research Hospital Eye Clinic, İzmir Katip Çelebi University Faculty of Medicine between January 2009 and December 2014 with canalicular injury and who underwent canalicular laceration repair by a single surgeon were included in the study. Approval was obtained from the ethics committee of İzmir Katip Çelebi University Faculty of Medicine. The following data were recorded: demographic details of the patients, cause of 
injury, eye findings associated with the damaged canaliculus, length of time between injury and operation, date of removal of tube, and length of follow-up period. Trauma causing canalicular laceration was classified as direct (penetrating injury usually with a sharp object) or avulsive (secondary to forces leading to traction on the eyelid).

Surgical intervention was performed using operating room microscope. When proximal and distal ends of canalicular laceration could be identified, monocanalicular silicone tube implantation was performed with mini-Monoka. In cases where distal end was not visible, pigtail probe was used and bicanalicular annular silicone tube intubation was performed. In all patients, canalicular edges were approximated using 8-0 vicryl sutures. Next, any accompanying lid laceration or canthal dislocation was addressed to ensure tissue integrity.

During the postoperative period, eye drops containing tobramycin and dexamethasone were applied 4 times a day, I drop each, for 2 weeks. Postoperative follow-up was done at I week, I month, 3 months and 6 months after the operation. Tube was scheduled to be removed at 3 months post-

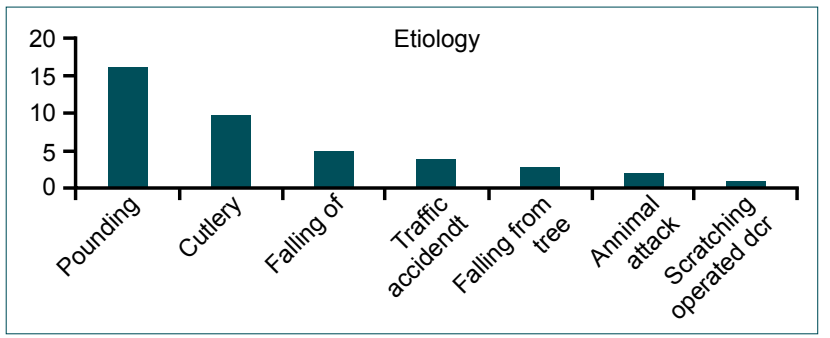

Figure 1. The etiology of canalicular trauma.
Table I. Survey

I Do you experience tearing of the operated eye?
$2 \quad \begin{aligned} & \text { Is there any difference compared with the other eye } \\ & \text { in terms of tearing? }\end{aligned}$
$3 \quad$ If there is tearing, does it occur indoors, outdoors, or
both?

Table 2. Munk score

\begin{tabular}{|c|c|}
\hline Grade 0 & No epiphora \\
\hline Grade I & $\begin{array}{l}\text { Occasional epiphora, requiring dabbing less than } \\
\text { twice a day }\end{array}$ \\
\hline Grade 2 & Epiphora requiring dabbing 2-4 times per day \\
\hline Grade 3 & Epiphora requiring dabbing 5-10 times per day \\
\hline Grade 4 & Epiphora requiring dabbing more than 10 times per day \\
\hline
\end{tabular}

procedure. Anatomical and functional success was assessed at follow-up after tube removal. Anatomical success was defined as patency of canaliculus to irrigation with saline. Functional success was evaluated with a brief questionnaire (Table I) and appraisal of patient experience of epiphora using Munk score (Table 2).

\section{RESULTS}

Mean age of 35 (85\%) male and 6 (15\%) female patients who underwent unilateral canalicular laceration repair was $31.85 \pm 18.9$ years (range: $1-79$ years).
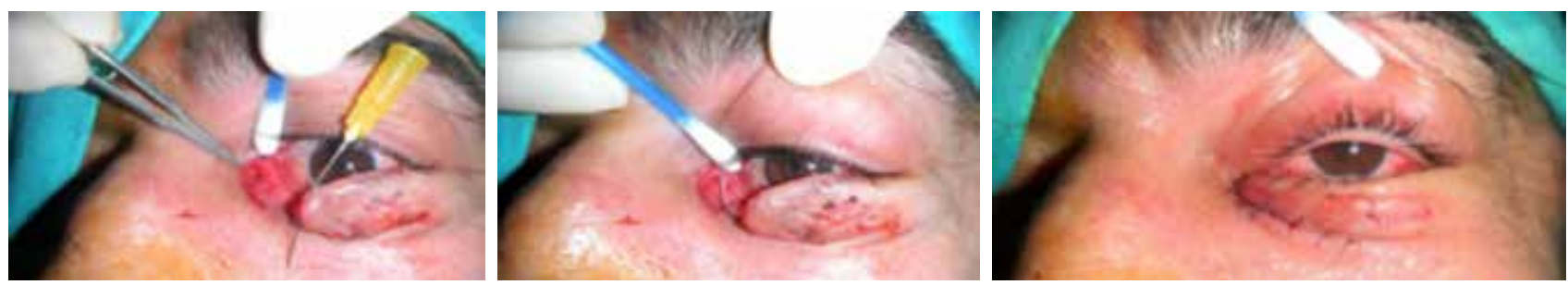

Figure 2. Monocanalicular tube intubation.
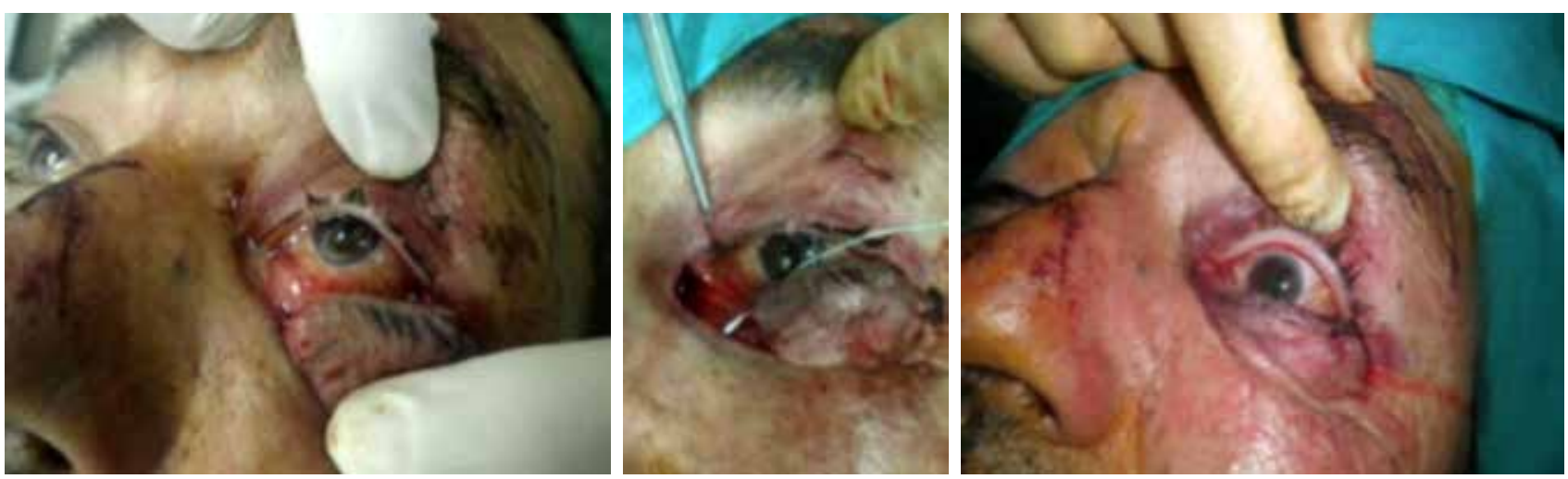

Figure 3. Detection of distal end via pigtail probe. 


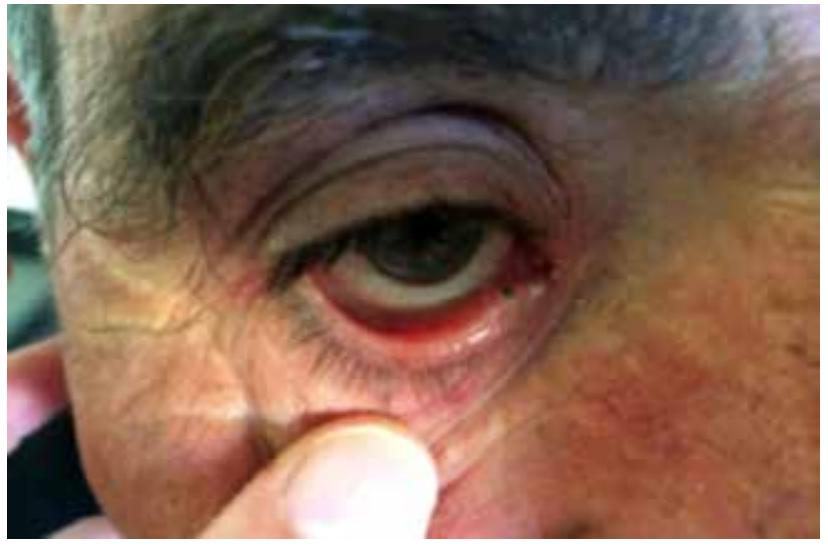

Figure 4. The patient with Monoka tube attached for 2 years.

Avulsive traumas made up $66 \%(n=27)$ of injuries in study group, while $34 \%(n=14)$ were direct (penetrating) injuries. Classification made based on etiology of trauma revealed that among 41 patients, 16 suffered canalicular damage as result of blow/punch, 10 patients were wounded with sharp object, 5 patients fell from height, 4 patients were injured in traffic accident, 3 fell from tree, 2 suffered animal attack, and I patient "was scratching his eyelid after dacryocystorhinostomy" (Figure I).

Distribution of trauma according to location of laceration was as follows: $63.4 \%(n=26)$ occurred in left inferior canaliculus, $19.5 \%(n=8)$ were seen in right inferior canaliculus, $9.8 \%(n=4)$ in right superior canaliculus, and $7.3 \%(n=3)$ in left superior canaliculus. Left inferior canaliculus was most frequent site of injury.

There was additional injury in $28(68.3 \%)$ patients of the 4 I patients included in the study: eyelid injury in 26 (92.9\%), corneal perforation in I patient (3.6\%), and nasal fracture in the other (3.6\%).

Microsurgery was performed, on average, within $39 \pm 27.8$ hours of time of injury; 3 hours was soonest and 14 days was latest. General anesthesia was used for $78 \%(n=32)$ of the patients, while local anesthesia was used for $14.6 \%(n=6)$, and sedation anesthesia for remaining $7.4 \%(n=3)$.

Monocanalicular intubation was performed in 31 cases and bicanalicular annular intubation with pigtail probe (Figure 2, 3) in 10.

Mean follow-up period was $6 \pm 5.7$ months (range: 1-19 months). Tubes were removed at average of $5.1 \pm 4$ months (range: I-24 months). One patient did not return for removal procedure and Monoka tube remained attached at inferior punctum for 2 years (Figure 4). Tube was displaced in the first week in I case due to patient rubbing eyelid.

Lavage revealed patency in all patients. Anatomical success was evaluated as $100 \%$. On questionnaire, 2 patients indi- cated mild tearing in operated eye, though with no difference in the other eye. Munk score was grade 0 in all patients.

\section{DISCUSSION}

Due to their anatomical location, canaliculi can easily be affected by orbital trauma. When canalicular trauma is suspected, first of all, detailed examination should be performed under a microscope. If this is insufficient, lavage cannula should be employed to examine the canaliculus.

Canalicular damage may be classified as result of direct or avulsive injury; however, precise boundaries to distinguish groups are very difficult to implement. While sharp, cutting objects produce clean, straight laceration, effects of many types of blunt trauma can lead to avulsion of the canalicular structures. Incidents that exert tearing force on the lid, such as blunt trauma, traffic accidents, blow with club or similar tool, or a fall can induce lacerations, particularly in weak canalicular portion of the eyelid. Jordan et al. reported that direct injury was responsible for laceration in more than half (54\%) of cases. ${ }^{[5]}$ In 25-case review conducted by Wulc et al., they reported $84 \%$ avulsive injury and $16 \%$ direct injury. [6] In the present study, too, avulsive injury was observed in majority of the patients; however, it seems that this classification is not used in many series regarding canalicular laceration. ${ }^{[7-9]}$

Canalicular laceration is especially seen in children and young adults. In 222-case series of Kennedy et al., mean age was 20 years. $^{[10]}$ Naik et al. reported in a 24 -case series that age range of patients was 10 months to 52 years, with mean age of 16 years. ${ }^{[1]}$ In study conducted by Argın et al. ${ }^{[2]}$ in our country, mean age was $2 \mathrm{I}$ and age ranged between $\mathrm{I} .5$ and 64 years. Mean age was 31 years in study reported by Demir et al. ${ }^{[13]}$ Similarly, in this study, there was broad age range in patient group composed primarily of young adults (mean age: 31 years).

Gender distribution in this study is similar to that seen in the literature, and there is an obvious male predominance. In study conducted by Kennedy et al., ${ }^{[10]} 166$ (75\%) of 222 patients were male. Argın et al. ${ }^{[12]}$ reported all 10 cases were male, and $15(75 \%)$ of 20 cases were male in the study of Demir et al. ${ }^{[13]}$ As for the present study, $85 \%$ of the 41 patients were male and $15 \%$ were female. Given that the most common cause of trauma was blow/punch, male predominance is not surprising.

Kennedy et al. ${ }^{[10]}$ reported $66 \%$ inferior canaliculus, $28 \%$ superior canaliculus, and $6 \%$ both canaliculi affected. Jordan et al. $^{[5]}$ found inferior laceration in $50 \%$, superior laceration in $23 \%$, and bicanalicular laceration in $4 \%$ of cases. In the present study, percentage of inferior canalicular injury cases was $83 \%(n=34)$, whereas superior canaliculus was site of trauma in $17 \%(n=7)$. There were no cases of injury to both canaliculi. 
Table 3. The number of canalicular repair cases and success rates seen in the literature

\begin{tabular}{|c|c|c|c|}
\hline Author & Number of cases & Treatment method & Functional success (\%) \\
\hline Jordan D.R. & 222 & Bicanalicular annular & 97 \\
\hline Liu Z. & 47 & Bicanalicular annular & 96 \\
\hline Lee $\mathrm{H}$. & 36 & Monocanalicular & 92 \\
\hline Wu S.Y. & 98 & Bicanalicular annular & 84 \\
\hline Kersten R.C. & 67 & Bicanalicular annular & 97 \\
\hline Saunders D.H. & 51 & Bicanalicular annular & 73 \\
\hline Canavan Y.M. & 57 & Varied & 38 \\
\hline Hing S.J. & 42 & Bicanalicular annular & 42 \\
\hline Walter W.L. & 18 & Bicanalicular annular & 100 \\
\hline Garber P.F. & 17 & Monocanalicular & 100 \\
\hline Hawes M.J. & 24 & Bican.nasal & 95 \\
\hline Argın A. & 10 & Varied & 100 \\
\hline Yaman A. & 3 & Varied & 100 \\
\hline Oltulu R. & 17 & Monocanalicular & 100 \\
\hline Kuru Ö. & 15 & Monocanalicular & 93 \\
\hline Yener $\mathrm{H}$. & 20 & Bicanalicular annular & 100 \\
\hline Şendul S.Y. & 44 & Monocanalicular & 93 \\
\hline Demir T. & 20 & Bicanalicular annular & 100 \\
\hline
\end{tabular}

Canalicular injury can be accompanied by other injuries to the eye. It has been reported that the most frequently seen accompanying injuries are eyelid laceration, hyphema, corneal abrasion, and globe perforation. ${ }^{[14]}$ In this study, $28(68 \%)$ of $4 \mathrm{I}$ patients had additional eye injuries. Most common was laceration of other parts of the eyelid.

Ideal length of period between canalicular trauma and surgery for repair is questionable. Edema and wound healing response at ends of the canalicular and pericanalicular tissue can make it difficult to determine localization of distal edge of laceration. [10] For this reason, it is recommended that repair should be performed within first 24 to 48 hours after trauma. However, authors such as Hawes et al. have reported successful surgical correction can be performed within first 5 days. ${ }^{[15]}$ Kennedy et al. did not establish any correlation between period post trauma and surgery and postoperative epiphora. ${ }^{[10]}$ In the present study, surgery was performed at average of 39 hours, with 3 hours after injury the soonest, and 14 days the latest, and anatomical and functional success was achieved in all patients. High success rate achieved in this study suggests that treatment provided by experienced team in appropriate conditions is more important than length of time before operation.

The first step in canalicular repair is to find distal part of the canaliculus. Viscoelastic substances, air, water, methylene blue, or fluorescein may be injected into the lacrimal sac through non-traumatic canaliculus to aid visualization. ${ }^{[7,8]}$ In addition, pigtail probe may be used to detect distal end of cut. ${ }^{[5]} \mathrm{Al}-$ though high surgical success rates have been reported with pigtail probe and annular intubation, this technique has disadvantages of creating false passage and causing damage to the unaffected canaliculus. ${ }^{[16]}$ Surgeon using this method must be experienced and avoid iatrogenic damage to robust nasolacrimal tissues. Another preferred type of intubation is bicanalicular nasal intubation, which, in addition to the risks of annular intubation, also carries risk of damage due to passing through nasal passage. ${ }^{[17]}$

In this study, canalicular laceration repair and mini-Monoka tube implantation was performed in 31 patients, and pigtail probe and annular intubation were used in 10 cases. Excellent results were obtained with both methods, and no difference was observed in terms of anatomical or functional success.

There is no consensus on period of time silicone tube is to remain in place in case of canalicular trauma; recommended period varies from 3 months to I year. ${ }^{[18,19]}$ Conlon et al., in an animal model, determined higher canalicular patency when removed at 12 weeks compared to 4 or 8 weeks, and reported that 12 weeks was optimal duration before extraction. [20] In this study, although intended duration was 3 months, removal occurred later (mean: 5.1 months) due to the fact that follow-up did not take place as scheduled. No complaints of irritation as result of delay were recorded.

Most important complication related to monocanalicular intubation is early tube dislocation. Anastas et al. reported 
29\% occurrence. ${ }^{[21]}$ However, in 19-patient series of Leibovitch et al., early tube dislocation was not observed in any patient. ${ }^{[22]}$ Risk of early tube dislocation can increase, especially in children, due to rubbing and scratching. This complication was only seen in I case in this study, when 7-year-old child rubbed his eyelid.

Canalicular repair generally has high success rate. ${ }^{[5,12,13,16,23-33]}$ Bicanalicular intubation has rate ranging from $30 \%$ to $100 \%$. $[5,13,15,26,31]$ Jordan et al. ${ }^{[5]}$ reported success rate of $94 \%$ in large series, which included 222 bicanalicular intubations. Success rate in binasal intubation series of 24 cases reported by Hawes et al. was $95 \% .{ }^{[15]}$ Success rate of monocanalicular intubation method has been reported in the range of $60 \%$ to $100 \% .^{[21-23,30,32,33]}$

High rate of success has also been described in some studies conducted in our country. Argın et al., ${ }^{[12]}$ Yaman et al., ${ }^{[29]}$ and Oltulu et al. reported success rate of $100 \% .^{[30]}$ In 20 cases of bicanalicular annular intubation performed by Yener et al., anatomical success rate and functional success rate were reported as $100 \%$ and $95 \%$, respectively. ${ }^{[31]}$ Early tube dislocation was seen in I of 15 cases of monocanalicular intubation reported by Kuru et al., and anatomical and functional success rate were each reported as $93 \%$ in that study. ${ }^{[32]}$ Demir et al. reported 100\% anatomical success and $95 \%$ functional success in 20-patient series. ${ }^{[13]}$ Şendul et al. reported $97 \%$ anatomical success and $93 \%$ functional success in 44 -case series. $^{[33]}$ (Table 3 ) In present study, anatomical and functional success rate was determined to be $100 \%$.

It is widely thought that inferior canalicular laceration repair is more important and requires mandatory treatment because of the belief that it has more significant role in drainage. Therefore, repair of superior canalicular laceration may be ignored. Contrary to that general belief, however, Daubert et al. found that inferior and superior canaliculi were equally involved in tear drainage in a scintigraphic study. ${ }^{[34]}$ Moore and Linberg, in an experimental study in which they obstructed single canalicular, determined that subjective findings occur in $56 \%$ of upper canalicular obstruction events, and in $63 \%$ of lower canalicular obstructions, and concluded that both canaliculi have equal role. ${ }^{[35]}$ The present study had limited number of upper canalicular lacerations, and anatomical and functional success was obtained in all of the superior and inferior canalicular lacerations.

Surgical repair of canalicular trauma yields extremely successful results. Use of modern microsurgical techniques by an experienced team with proper stent use during the healing process ensures good outcome. Though injury may be to only I canaliculus, patients need not live with single canaliculus. There is possibility of future additional trauma. Canalicular repair should definitely be performed; however it is important that the surgery be performed under appropriate conditions and by an experienced team.
Conflict of interest: None declared.

\section{REFERENCES}

1. McCord CD. The lacrimal drainage system. In: Duane TD, Jaeger EA, eds. Clinical Ophthalmology. Philadelphia: Harper\&Row Pub, 1985:1.

2. Royer J, Adenis JP, Bernard JA. Lappareil Lacrimal. Paris: Masson 1982;17:25-75.

3. Menteş J. Lakrimal sistem; anatomi, fizyoloji, fizyopatoloji. In: Hasanreisoğlu B, editör. XI. Ulusal Oftalmoloji Kursu Bülteni. Ankara: Yildırım Ofset Basımevi; 1991. s. 18-28.

4. Günenç Ü, Maden A. Kapak yaralanmalarında silikon tüp ile kanalikül rekonstrüksiyonu. Türkiye Klinikleri Oftalmoloji 1995;4:1-4.

5. Jordan DR, Ziai S, Gilberg SM, Mawn LA. Pathogenesis of canalicular lacerations. Ophthal Plast Reconstr Surg 2008;24:394-8. Crossre

6. Wulc AE, Arterberry JF. The pathogenesis of canalicular laceration. Ophthalmology 1991;98:1243-9. Crossret

7. Morrison FD. An aid to repair of lacerated tear ducts. Arch Ophthalmol 1964;72:341-2. Crossret

8. Lerner HA, Boynton JR. Sodium hyaluronate (Healon) as an adjunct to lacrimal surgery. Am J Ophthalmol 1985;99:365. Crossret

9. Yang X, Jin T, Pang X. Repair of a canalicular laceration in a neonate. J Pediatr Ophthalmol Strabismus 2005;42:306-7.

10. Kennedy RH, May J, Dailey J, Flanagan JC. Canalicular laceration. An 11-year epidemiologic and clinical study. Ophthal Plast Reconstr Surg 1990;6:46-53. Crossre

11. Naik MN, Kelapure A, Rath S, Honavar SG. Management of canalicular lacerations: epidemiological aspects and experience with Mini-Monoka monocanalicular stent. Am J Ophthalmol 2008;145:375-380. Crossre

12. Argın A, Demir MN, Duman S. Kanalikül kesilerinde onarım teknikleri. Türk Oftalmoloji Gazetesi 2001;31:327-32.

13. Demir T, Gül FC. Results of Canalicular Laceration Reperation by Pigtail Probe and Silicon Tube Entubation. İnönü Üniversitesi Tip Fakültesi Dergisi 2011;18:87-90.

14. Tazartès M, Bénarafa H. Orbital, eyelid and lacrimal trauma. [Article in French] Rev Prat 1995;45:437-41. [Abstract]

15. Hawes MJ, Segrest DR. Effectiveness of bicanalicular silicone intubation in the repair of canalicular lacerations. Ophthal Plast Reconstr Surg 1985;1:185-90. Crossre

16. Walter WL. The use of the pigtail probe for silicone intubation of the injured canaliculus. Ophthalmic Surg 1982;13:488-92.

17. Garber PF. Management of injuries to the lacrimal system, in bosniak. SL (ed). Advences in opthalmic plastic and recosntructive surgery. The lacrimal system Vol 3 New york Pergamon press 1984;175-95.

18. Kersten RC, Kulwin DR. "One-stitch" canalicular repair. A simplified approach for repair of canalicular laceration. Ophthalmology 1996;103:785-9. Crossret

19. Liang T, Zhao KX, Zhang LY. A clinical application of laser direction in anastomosis for inferior canalicular laceration. Chin J Traumatol 2006;9:34-7.

20. Conlon MR, Smith KD, Cadera W, Shum D, Allen LH. An animal model studying reconstruction techniques and histopathological changes in repair of canalicular lacerations. Can J Ophthalmol 1994;29:3-8.

21. Anastas CN, Potts MJ, Raiter J. Mini Monoka silicone monocanalicular lacrimal stents: Subjective and objective outcomes. Orbit 2001;20:189200. Crossre]

22. Leibovitch I, Kakizaki H, Prabhakaran V, Selva D. Canalicular lacerations: repair with the Mini-Monoka ${ }^{\circ}$ monocanalicular intubation stent. 
Ophthalmic Surg Lasers Imaging 2010;41:472-7. Crossree

23. Lee H, Chi M, Park M, Baek S. Effectiveness of canalicular laceration repair using monocanalicular intubation with Monoka tubes. Acta Ophthalmol 2009;87:793-6. Crossre.

24. Wu SY, Ma L, Chen RJ, Tsai YJ, Chu YC. Analysis of bicanalicular nasal intubation in the repair of canalicular lacerations. Jpn J Ophthalmol 2010;54:24-31. Crossre

25. Liu Z, Sha X, Liang X, Wang Z. Use of silicone tubes to repair canalicular lacerations via a novel method. Eye Sci 2013;28:195-200.

26. Saunders DH, Shannon GM, Flanagan JC. The effectiveness of the pigtail probe method of repairing canalicular lacerations. Ophthalmic Surg 1978;9:33-40.

27. Canavan YM, Archer DB. Long term rewİev of injuries to the lacrimal drainage apparatus. Trans optahlmol Soc UK 1979;99:201-4.

28. Hing SJ. A retrospective study of lacrimal canaliculus injuries in Auckland. Trans Ophthalmol Soc N Z 1984;36:72-3.

29. Yaman Aylin. Kanalikül kesilerinde Tedavi yaklaşımı. DEÜ Tıp Fakültesi Dergisi 2007;21:81-7.
30. Oltulu R. Lakrimal kanalikül Travmalı olguların değerlendirilmesi. Turk J Ophthalmol 2014;44:219-22.

31. Yener Hİ, Gül A, Kılıç A, Çinal A, Yaşar T, Demirok A. Annular Silicon Tube Intubation With Pigtail Probe In Canalicular Injuries. Dicle Tip dergisi 2008;35:245-8.

32. Kuru Ö, Yuttaşer Ocak S, Yıldırım MA, Erden B, Aslankurt M, Elçioğlu MN. Clinical Features of Patients with Post-Traumatic Canalicular Laceration and the Effectiveness of Surgical Repair with Monoka Tube Intubation. Turk J Ophthalmol 2015;45:14-7. Crossret

33. Şendul SY, Çağatay HH, Dirim B, Demir M, Çınar S, Üçgül C, et al. Reconstructions of Traumatic Lacrimal Canalicular Lacerations: A 5 Years Experience. The Open Access Journal of Science and Technology 2015;3:6. Crossre]

34. Daubert J, Nik N, Chandeyssoun PA, el-Choufi L. Tear flow analysis through the upper and lower systems. Ophthal Plast Reconstr Surg 1990;6:193-6.v

35. Moore CA, Linberg JV. Symptoms of canalicular obstruction. Ophthalmology 1988;95:1077-9. Crossre

\section{ORIJINAL ÇALIŞMA - ÖZET}

\section{Travmatik kanalikül kesi tamiri yapılan hastalarda anatomik ve fonksiyonel başarının değerlendirilmesi}

\section{Dr. Hasan Aytoğan, ${ }^{1}$ Dr. Şeyda Karadeniz Uğurlu²}

${ }^{1}$ Tepecik Eğitim ve Araştırma Hastanesi, Göz Hastalıkları Kliniği, İzmir ${ }^{2}$ Katip Çelebi Üniversitesi Tıp Fakültesi, Göz Hastalıkları Anabilim Dalı, İzmir

AMAÇ: Tek taraflı kanaliküler kesi tamiri uygulanan hastalarda anatomik ve fonksiyonel başarıyı değerlendirmek.

GEREÇ VE YÖNTEM: I Ocak 2009 ile 3I Aralık 2014 tarihleri arasında tek cerrah tarafından kanalikül kesi tamiri yapılan hastalar çalışmaya dahil edildi. Hastaların demografik verileri, travmanın zamanı ve etkeni, uygulanan cerrahi yöntem ve izlem süreleri kaydedildi. Hastaların sulanma yakınmaları cerrahi sonrası entübasyon tüpünün çıkarılmasını takiben en son kontrol muayenede Munk skorlamasına göre değerlendirildi. Gözyaşı yolunun açıklığı kanaliküler irigasyon ile incelendi.

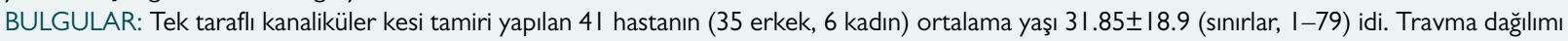
indirekt-avülsif yaralanma \%66 ( $n=27)$, direkt-penetran yaralanma \%34 $(n=14)$ şeklindeydi. Kesi yeri sol alt kanalikül \%63.4 ( $n=26)$, sağ alt kanalikül \% $19.5(n=8)$ sağ üst kanalikül \%9.8 $(n=4)$ ve sol üst kanalikül \%7.3 $(n=3)$ olarak saptandı. Kırk bir hastadan I0'una pigtai lprob ile bikanaliküler anüler entübasyon uygulanırken, 3 I hastaya monokanaliküler entübasyon uygulandı. İlem süresi ortalama $6 \pm 5.7$ ay idi. Hastaların tümünde lavaj açık bulundu. Munk skoru hastaların tamamında grade 0 olarak belirlendi.

TARTIŞMA: Günümüzde mikrocerrahi yöntemlerle yapılan kanalikül kesi tamiri ile çok başarılı sonuçlar elde edilmektedir. Anahtar sözcükler: Epifora; göz yaşı menisküsü; travmatik kanlikül kesisi.

Ulus Travma Acil Cerrahi Derg 2017;23(I):66-71 doi: 10.5505/tjtes.2016.6502। 